\title{
Viabilidad de utilización de una pasta de cemento con nanofibras de carbono como ánodo en la extracción electroquímica de cloruros en hormigón
}

\section{Usability of cement paste containing carbon nanofibres as an anode in electrochemical chloride extraction from concrete}

\author{
B. del Moral(*), Ó. Galao(*), C. Antón ${ }^{(*)}$, M. A. Climent(*), P. Garcés ${ }^{(*)}$
}

Recibido/Submitted: 26-V-2011

Aceptado/Accepted: 15-II-2012

Publicado online/Online publishing: 22-VI-12

RESUMEN

En la aplicación de la técnica de extracción electroquímica de cloruros (EEC), tradicionalmente se ha venido empleando como ánodo externo una malla de $\mathrm{Ti}^{-\mathrm{RuO}_{2}}$. En este artículo se aportan los resultados de investigaciones basadas en la utilización de ánodos formados por pasta de cemento conductora con adición de nanofibras de carbono (NFC) y su aplicación en EEC. Las experiencias se desarrollaron en probetas de hormigón contaminado previamente con cloruro. Las eficiencias alcanzadas se compararon con las obtenidas empleando un ánodo tradicional $\left(\mathrm{Ti}_{-} \mathrm{RuO}_{2}\right)$, así como pastas de cemento con adición de otros materiales carbonosos. Los resultados muestran la viabilidad en la utilización de la pasta de cemento conductora con NFC como ánodo en la aplicación en EEC en hormigón, encontrándose eficiencias similares a las obtenidas con la tradicional malla de $\mathrm{Ti}-\mathrm{RuO}_{2}$ pero teniendo la ventaja añadida sobre esta de que es posible adaptarla a geometrías estructurales complejas al ser aplicada en forma de pasta.

Palabras clave: extracción electroquímica de cloruros, pasta de cemento conductora, nanofibras de carbono, reparación.

\section{SUMMARY}

In the application of the electrochemical chloride extraction (ECE) technique, traditionally, the $\mathrm{Ti}^{-\mathrm{RuO}} \mathrm{O}_{2}$ wire netting has been used as the external anode. This article provides the results of the research based on the use of conductive cement paste with addition of carbon nanofibers (CNF) as anodes and its application in ECE. The tests were developed in concrete specimens previously contaminated with chloride. The efficiencies achieved were compared with those obtained using a traditional anode $\left(\mathrm{Ti}-\mathrm{RuO}_{2}\right)$ and cement pastes with the addition of other carbonaceous materials. The results show the feasibility of using conductive cement paste with CNF as the anode in the electrochemical extraction of chlorides in concrete, finding similar efficiencies to those obtained with traditional $\mathrm{Ti}-\mathrm{RuO}_{2}$ wire netting but with the added advantage that it can be adapted to complex structural geometries as it can be applied as a paste.

Keywords: electrochemical chloride extraction, conductive cement paste, carbon nanofibers, repair.

(*) Universidad de Alicante. (Alicante, España). 


\section{INTRODUCCIÓN}

Uno de los principales problemas que puede afectar al hormigón armado es la corrosión del acero embebido. Para devolver un hormigón que ha sufrido corrosión de armaduras a su estado inicial de puesta en obra es necesario reparar los daños producidos. Las reparaciones tradicionales consisten básicamente en la eliminación del hormigón dañado y posiblemente contaminado por cloruros, la limpieza adecuada de las armaduras, y en ocasiones sustitución, y la posterior reposición del hormigón eliminado. Pero dichas reparaciones presentan bastantes inconvenientes; sobre todo, un coste económico muy alto, además de trabajos muy laboriosos, lentos, suciedad, ruido, etc.

Una solución alternativa, si el hormigón está contaminado por cloruros, es la técnica de extracción electroquímica de cloruros (EEC) (1-19). Esta técnica se basa en la utilización del sistema de electrolisis para la extracción de los cloruros presentes en el hormigón. Los cloruros $\left(\mathrm{Cl}^{-}\right)$son iones cargados negativamente. Mediante el paso de corriente continua entre la armadura, que actúa como cátodo (se conecta al polo negativo de la fuente de alimentación), y una disposición externa, que actúa como ánodo (se conecta al polo positivo de la fuente de alimentación), se fuerza a los cloruros a migrar hacia el exterior a través de la estructura porosa del hormigón por la acción del campo eléctrico creado. Así no es necesario sustituir el hormigón contaminado y, una vez extraída una cantidad suficiente de cloruros, se aumenta la vida útil de la estructura.

Numerosos autores han estudiado diferentes variables relacionadas con la aplicación de la EEC (1-19) en general. Se han expresado dudas respecto a aspectos tales como la determinación del punto final de la técnica (cantidad de carga a pasar) $(11,13)$, efectos colaterales de la técnica (7-10) y la eficiencia a largo plazo (19). Asimismo se ha puesto de manifiesto que la EEC, a pesar de ser capaz de extraer una parte importante de los iones $\mathrm{Cl}^{-}$presentes en el hormigón, es incapaz de detener la corrosión si las armaduras de acero se encuentran en un estado de corrosión avanzado $(15,18)$. Por todos estos hechos, la EEC sigue siendo objeto de investigación en la actualidad.

Recientemente se ha utilizado por primera vez una pasta de cemento conductora mediante adición de polvo de grafito como ánodo en la aplicación de esta técnica (20), en forma similar a como había sido utilizado tal tipo de ánodo en protección catódica $(21,22)$. Las eficiencias de estos ánodos, en relación a la extracción de $\mathrm{Cl}^{-}$, fueron similares a las obtenidas con un ánodo tradicionalmente usado en EEC, tal como la malla de $\mathrm{Ti}^{-\mathrm{RuO}_{2}}$ (20).

El objetivo principal del presente trabajo es comprobar la viabilidad del uso de una pasta de cemento conductora

\section{INTRODUCTION}

One of the main vulnerabilities of reinforced concrete, corrosion of its embedded steel, causes damage that must be repaired if the concrete is to be restored to its initial condition. Traditionally, this has entailed eliminating the damaged and possibly chloride-contaminated concrete, cleaning or replacing the reinforcing steel and re-casting the concrete. Such operations are characterised by a number of drawbacks: they are costly, labour-intensive and time-consuming and generate grime and noise.

An alternative solution, if the concrete damage is caused by chlorides, is electrochemical chloride extraction (ECE) (1-19). This technique extracts the chlorides $\left(\mathrm{Cl}^{-}\right.$, negatively charged ions) present in concrete by electrolysis. The electrical field generated between the reinforcing steel, which acts as a cathode (connected to the negative pole on the power supply), and an external device that acts as an anode (connected to the positive pole on the power supply), forces the chlorides to flow outward through the concrete pores. The chloridecontaminated concrete need not be replaced and once a sufficient amount of chlorides is extracted, the service life of the structure is lengthened.

Several authors have studied the variables involved in ECE (1-19) in general. Doubts have been raised around issues such as the determination of the end point (amount of charge that needs to be extracted) $(11,13)$, side effects (7-10) and long-term effectiveness (19). While ECE can extract a substantial proportion of the $\mathrm{Cl}^{-}$ions in concrete, it has been shown to be unable to detain corrosion in severely corroded reinforcing steel $(15,18)$. For all these reasons, ECE continues to be a subject of current research.

A conductive cement paste containing graphite powder was recently used for the first time as an ECE anode (20), emulating prior use of the material as an anode in cathodic protection $(21,22)$. This anode was found to deliver $\mathrm{Cl}^{-}$extraction values comparable to the levels observed for traditional ECE anodes such as $\mathrm{Ti}^{\mathrm{RuOO}} \mathrm{O}_{2}$ wire mesh (20).

The present study aimed primarily to verify the usability of conductive cement paste containing carbon 
mediante adición de nanofibras de carbono (NFC), como ánodo en la aplicación de la EEC. Se compara la eficiencia obtenida con NFC con la correspondiente a otros materiales carbonosos y con una malla de $\mathrm{Ti}^{-\mathrm{RuO}_{2}}$.

El uso de una pasta de cemento conductora mediante adición de NFC, en particular, o de otros materiales carbonosos, en general, ofrece una serie de ventajas como son la posibilidad de aplicación a cualquier tipo de superficie, adaptabilidad, flexibilidad, etc., que no están al alcance de otras disposiciones anódicas tradicionales.

\section{EXPERIMENTAL}

\subsection{Probetas de hormigón y ánodos de pasta de cemento conductora}

Se fabricaron bloques de hormigón cuya dosificación y características se muestran en la Tabla 1 . Se utilizó cemento tipo CEM II / B-L 32,5N siguiendo la norma CE UNE-EN 197-1:2000. Los áridos utilizados fueron de naturaleza caliza, procedentes de machaqueo, usándose dos tipos: grava y arena. El tamaño máximo del árido era de $20 \mathrm{~mm}$.

Los bloques de hormigón para los ensayos de EEC fueron fabricados utilizando moldes de madera de dimensiones $180 \times 180 \times 50 \mathrm{~mm}^{3}$ (ver Figura 1) y preparados en el laboratorio $20{ }^{\circ} \mathrm{C}$ y $90 \% \mathrm{HR}$ mediante amasado y compactación mecánica. Se fabricaron con adición de $\mathrm{NaCl}$ (contaminación artificial) en el agua de amasado, con una dosificación del $2 \%$ de $\mathrm{Cl}^{-}$en relación al peso de cemento. Se utilizó un plastificante libre de cloruros para el amasado. Inmediatamente después de la preparación, los bloques, dentro del molde, fueron recubiertos con una película de polietileno de 0,2 mm de grosor para mantener las condiciones de temperatura y humedad. Estando aún fresco el hormigón, se introdujo parcialmente un cubo sin fondo de PVC en la superficie del hormigón, a modo de piscina, con nanofibres (CNF) as an anode in ECE, by comparing its performance to the efficiency of other carbonaceous materials and a $\mathrm{Ti}-\mathrm{RuO} \mathrm{O}_{2}$ wire mesh.

The advantage of conductive cement pastes containing CNF in particular or other carbonaceous materials in general over traditional anodes is their adaptability to any type of surface.

\section{EXPERIMENTAL}

\subsection{Concrete specimens and conductive cement paste anodes}

Concrete blocks were prepared to the dosage and characteristics shown in Table 1.The cement used was Spanish and European standard UNE-EN 197-1:2000 type CEM II / B-L 32.5N.The aggregate, both coarse and fine, was crushed limestone with a maximum size of $20 \mathrm{~mm}$.

The concrete blocks for the ECE trials were mixed and mechanically compacted in the laboratory at $20^{\circ} \mathrm{C}$ and 90\% RH and cast in $180 \times 180 \times 50-\mathrm{mm}^{3}$ wooden moulds (see Figure 1). $\mathrm{Cl}^{-}$in the form of $\mathrm{NaCl}$ was added to the mixing water as artificial contamination at a rate of 2 wt\% (of the cement). A chloride-free plasticiser was added during mixing. Immediately after the concrete was poured into the moulds, the specimens were covered with a $0.2-\mathrm{mm}$ thick polyethylene film to ensure constant temperature and humidity. When the concrete was still fresh, a bottomless PVC vat was partially sunken into the concrete surface to form a pool to house the initial electrolyte that would collect the chlorides extracted. The blocks were removed from the

Tabla 1 / Table 1

Dosificación del hormigón.

Concrete dosage.

\begin{tabular}{|c|c|}
\hline Materiales / Material & Dosificación / Dosage \\
\hline Cemento / Cement & $250 \mathrm{~kg} / \mathrm{m}^{3}$ \\
\hline Relación a/c / W/c ratio & 0.65 \\
\hline Agua / Water & $162.5 \mathrm{l} / \mathrm{m}^{3}$ \\
\hline Grava / Coarseaggregate & $1000 \mathrm{~kg} / \mathrm{m}^{3}$ \\
\hline Arena / Fines & $890 \mathrm{~kg} / \mathrm{m}^{3}$ \\
\hline Plastificante / Plasticiser & $2.5 \mathrm{~kg} / \mathrm{m}^{3}$ \\
\hline
\end{tabular}


el fin de poder contener el electrolito inicial donde se recogen los iones cloruros extraídos. Pasadas 24 horas del amasado se desmoldaron y el curado de los mismos se realizó en cámara de humedad durante 28 días. Las caras laterales de los bloques de hormigón fueron recubiertas con mortero de sellado.

Las mezclas utilizadas como pasta cementicia conductora para la EEC tenían las dosificaciones presentadas en la Tabla 2. Se utilizaron diferentes valores para la relación agua/sólidos (a/s) debido al interés en conseguir trabajabilidades similares en todas las pastas, dadas las diferentes demandas de agua de cada material (Tabla 2). Se fabricaron cuatro bloques de hormigón para ensayar los cuatro tipos de ánodos conteniendo materiales carbonosos, véase Tabla 2. Después del curado de los bloques de hormigón, la pasta cementicia conductora fue extendida, a modo de enlucido en cada caso, sobre la cara superior del bloque de hormigón (ver Figura 1), con cuatro electrodos primarios de grafito (6 mm de diámetro y $100 \mathrm{~mm}$ de longitud) embebidos en la pasta. El espesor de la pasta ensayada fue de $7 \mathrm{~mm}$. Por último, se fabricó un quinto bloque de hormigón sin aplicación de pasta cementicia conductora y en su lugar se empleó un ánodo tradicional: malla de alambre de $\mathrm{Ti}^{-\mathrm{RuO}_{2}}$, previamente utilizado con resultados satisfactorios (12), con el fin de comparar el comportamiento de las pastas conductoras respecto a este ánodo tradicional. moulds 24 hours after casting and cured in a humidity chamber for 28 days, after which sealing mortar was applied to their side surfaces.

The mixes used as conductive cement paste in ECE were dosed as specified in Table 2. In light of the differences in water demand for each material, the water/solid (w/s) ratios were adapted to ensure that all the pastes exhibited similar workability (Table 2). Four concrete blocks were prepared for testing the four types of conductive cement paste anodes, see Table 2. A 7-mm layer of conductive cement paste, in which four primary, 6-mm diameter, 100- $\mathrm{mm}$ long graphite electrodes were embedded, was laid on the top of these 28-day concrete blocks (see Figure 1). Finally, a fifth concrete block was prepared to be used with a traditional anode for comparison: a Ti-RuO $\mathrm{O}_{2}$ wire mesh used in previous studies (12) with satisfactory results.

Tabla 2 / Table 2

Dosificaciones de las pastas cementicias conductoras. Conductive cement paste dosages.

\begin{tabular}{|c|c|c|c|c|c|}
\hline Ánodo / Anode & $\begin{array}{c}\text { Cemento / } \\
\text { Cement (g) }\end{array}$ & $\begin{array}{c}\text { Relación a/s* I } \\
\text { W/s ratio* }\end{array}$ & Agua / Water(g) & $\begin{array}{c}\text { Sustitución/Adición / } \\
\text { Replacement or addition <0\} }\end{array}$ & $\begin{array}{c}\text { Cantidad/ } \\
\text { Amount (g) }\end{array}$ \\
\hline $\begin{array}{c}\text { Nanofibras de carbón (NFC) / } \\
\text { Carbon nanofibres (CNF) }\end{array}$ & 160 & 1.7 & 340 & $\begin{array}{c}20 \% \text { Sustitución/ } \\
\text { Replacement }\end{array}$ & 40 \\
\hline $\begin{array}{c}\text { Polvo de grafito (PG) / } \\
\text { Graphite powder (GP) }\end{array}$ & 150 & 0.8 & 240 & $\begin{array}{c}50 \% \text { Sustitución/ } \\
\text { Replacement }\end{array}$ & 150 \\
\hline $\begin{array}{c}\text { Fibra de carbón de 3 mm (FC3) } \\
\text { / 3-mm carbon fibre (3CF) }\end{array}$ & 400 & 0.5 & 200 & $1 \%$ Adición / Addition & 4 \\
\hline $\begin{array}{c}\text { Negro de carbón (NC) / } \\
\text { Carbon black (CB) }\end{array}$ & 350 & 0.9 & 331 & $5 \%$ Adición / Addition & 17.5 \\
\hline
\end{tabular}

(*) Relación masa de agua/masa de sólidos (a/s) / Water/solid (w/s) ratio, bymass.

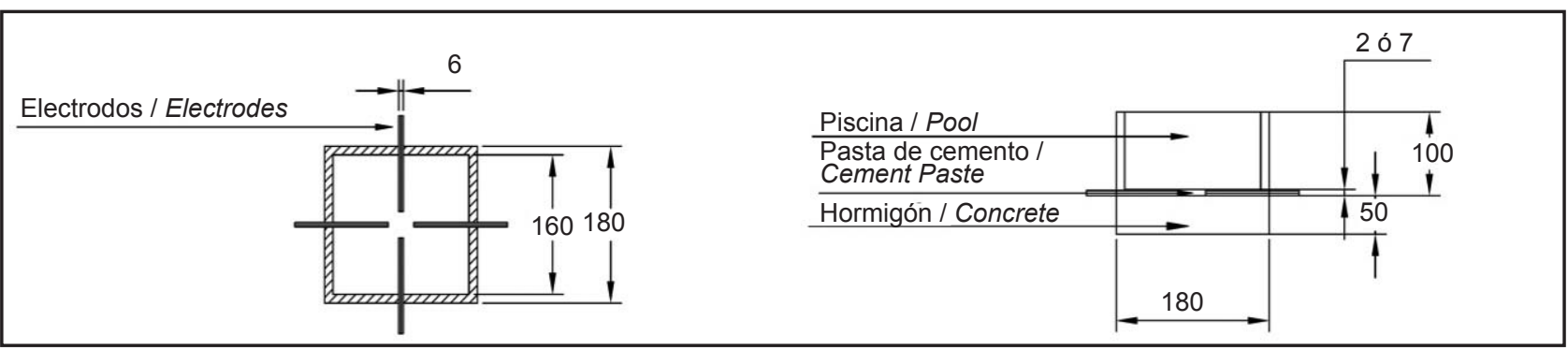

Figura 1. Vista superior y sección del bloque de hormigón y el montaje para los ensayos de EEC desarrollados utilizando como ánodo una pasta de cemento conductora.

Figure 1. Top and cross-section of concrete block and set-up for the ECE tests, in which the anode was conductive cement paste. 


\subsection{Características generales de los experimentos de extracción electroquímica de cloruros}

El electrolito inicial utilizado en los experimentos de EEC fue agua destilada situada sobre la pasta de cemento conductora. Como cátodo se utilizó una placa de acero de $160 \times 160 \times 2 \mathrm{~mm}^{3}$ que se colocó debajo del bloque de hormigón intercalando una esponja de polipropileno humedecida. Como ánodo se utilizó la pasta de cemento conductora aplicada sobre la superficie del bloque de hormigón, que se conectó al polo positivo de la fuente de alimentación mediante los electrodos de grafito. En el caso en que se utilizó como ánodo la malla de Ti$\mathrm{RuO}_{2}$, esta fue sumergida en el electrolito situado en la superficie del hormigón. El nivel del electrolito se mantuvo constante durante los periodos de paso de corriente. Todos los ensayos de EEC fueron llevados a cabo galvanostáticamente, a una densidad de corriente de $2 \mathrm{~A} / \mathrm{m}^{2}$. El área correspondía a la superficie expuesta de hormigón, que era igual a la superficie del ánodo, es decir, 160x160 mm² (ver Figura 1). La densidad de carga aplicada fue de $5 \times 10^{6} \mathrm{C} / \mathrm{m}^{2}$. La duración de la experiencia fue aproximadamente de $139 \mathrm{~h}$.

\subsection{Determinación de las eficiencias de los experimentos de EEC}

Para determinar la eficiencia de los experimentos de EEC se midieron las reducciones del contenido de $\mathrm{Cl}^{-}$en el hormigón. Para ello, al finalizar los experimentos de EEC, se obtuvieron muestras de hormigón pulverizado en capas de espesor $2 \mathrm{~mm}$ (23), desde la superficie sólida en contacto con el electrolito.

La determinación de los contenidos de $\mathrm{Cl}^{-}$soluble en ácido de las muestras de hormigón se realizó mediante valoración potenciométrica (24). Todas las concentraciones de $\mathrm{Cl}^{-}$del hormigón o de la pasta cementicia se expresan como porcentajes de $\mathrm{Cl}^{-}$soluble en ácido, relativo a masa total. Se tomaron también muestras del anolito al finalizar los ensayos de EEC, y se determinó su concentración de $\mathrm{Cl}^{-}$para conocer la cantidad de cloruros presentes en la fase líquida. Por integración de los perfiles de contenido de $\mathrm{Cl}^{-}$del hormigón y la pasta cementicia conductora, se pueden calcular las cantidades de cloruro presentes en cada una de estas fases antes y después de la EEC. Las distribuciones de contenido de $\mathrm{Cl}^{-}$en el hormigón, pasta cementicia conductora y electrolito, se calculan en términos de porcentajes referidos al contenido inicial de $\mathrm{Cl}^{-}$en el hormigón. Esto permite calcular directamente la eficiencia en la reducción del contenido de cloruro inicial.

\subsection{Electrochemical chloride extraction experiments, general characteristics}

The initial electrolyte used in the ECE experiments was distilled water poured over the conductive cement paste. The cathode, a $160 \times 160 \times 2-\mathrm{mm}^{3}$ steel plate, was placed underneath the concrete block, with a moist polypropylene sponge between the two. The anode was the conductive cement paste laid on the surface of the concrete block, which, via the graphite electrodes, was connected to the positive pole of the power source. Where the $\mathrm{Ti}^{-} \mathrm{RuO} \mathrm{O}_{2}$, mesh was used as an anode, it was submerged in the electrolyte lying on the surface of the concrete block. The electrolyte level was kept constant while the current was on. All the ECE trials were conducted galvanostatically at a current density of $2 \mathrm{~A} / \mathrm{m}^{2}$. The area was the exposed surface of the concrete, which was the same as the anode surface, i.e., $160 \times 160 \mathrm{~mm}^{2}$ (see Figure 1). A charge density of $5 \times 106 \mathrm{C} / \mathrm{m}^{2}$ was applied. The approximate duration of the experiment was $139 \mathrm{~h}$.

\subsection{Determination of ECE efficiency}

ECE efficiency was determined by measuring the decline in $\mathrm{Cl}^{-}$content in the concrete. To this end, after finishing the ECE trials, powder concrete samples, corresponding to $2 \mathrm{~mm}$ thick layers, were ground off the solid surface in contact with the electrolyte.

The acid-soluble $\mathrm{Cl}^{-}$content in the concrete samples was determined by potentiometric titration (24). All the $\mathrm{Cl}^{-}$concentrations in the concrete or cement paste were expressed as the percentage of the total mass of acidsoluble $\mathrm{Cl}^{-}$.Samples of the anolyte were taken after the ECE trials and their $\mathrm{Cl}^{-}$concentration was determined to calculate the amount of chlorides present in the liquid phase. The amount of chlorides in the concrete and the conductive cement paste were calculated before and after ECE by integrating the respective distribution curves. $\mathrm{Cl}^{-}$content distribution in the concrete, cement paste and electrolyte was calculated as the percentage of the initial $\mathrm{Cl}^{-}$content in the concrete. This was then used to calculate how efficiently the initial chloride content was lowered. 


\section{RESULTADOS Y DISCUSIÓN}

La Figura 2 muestra los perfiles de distribución-contenido en ión cloruro antes y después de la aplicación de la técnica de EEC en los bloques ensayados utilizando como ánodo pasta cementicia conductora mediante adición de NFC, comparativamente con otros materiales carbonosos y con la malla de $\mathrm{Ti}_{-} \mathrm{RuO}_{2}$. En todos los casos en que se utilizó material carbonoso, los ánodos se dispusieron de la misma forma, es decir, aplicándolos a modo de fina capa extendida y con el mismo espesor (7 mm). El origen de los datos de profundidad ha sido tomado desde la superficie del hormigón y no desde la superficie de la pasta de cemento conductora situada encima. Los porcentajes de cloruros están referidos a la masa de hormigón y no a la masa de cemento, para poder hacer comparables los resultados y dar un porcentaje global de cloruros. El contenido medio inicial de ión cloruro se sitúa en torno al 0,22\% respecto a la masa total de hormigón, que corresponde aproximadamente al $2 \%$ referido a la masa de cemento.

Si se comparan los perfiles de distribución de cloruros obtenidos, ver Figura 2, se comprueba que efectivamente se extraen cantidades considerables, más o menos del mismo orden. Como es sobradamente conocido los iones cloruro reaccionan con los aluminatos tricálcicos, presentes en la composición del cemento, formando la denominada "Sal de Friedel" $\mathrm{C}_{3} \mathrm{AH}_{10} \cdot \mathrm{CaCl}_{2}$ y $\mathrm{C}_{3} \mathrm{AH}_{32} \cdot 3 \mathrm{CaCl}_{2}$. Estos cloruros no se pueden eliminar mediante EEC debido a que no se ven afectados por la acción del campo eléctrico impuesto. Esta, además de otras razones, puede explicar por qué la eficiencia en la extracción de cloruros es menor del 100 . No obstante, un descenso del $\mathrm{pH}$ en la pasta cementicia, debido, por ejemplo, a la carbonatación del hormigón, invierte este proceso de fijación de cloruros, liberándolos de nuevo.

\section{RESULTS AND DISCUSSION}

Figure 2 shows the chloride ion content distribution before and after applying ECE to the blocks tested using CNF-containing conductive cement paste, other carbonaceous materials and $\mathrm{Ti}-\mathrm{RuO}_{2}$ wire mesh as the anodes. The anodes containing carbonaceous material were arranged in the same way on all the blocks, i.e., spreading a 7-mm layer of material over the surface. Depth was measured from the concrete surface, not from the outer layer of conductive cement paste. The chloride percentages were referred to the concrete rather than the cement mass to ensure comparability of the results and to obtain the overall percentage of chlorides. The initial mean chloride ion content was around $0.22 \%$ of total concrete mass or approximately $2 \%$ of the cement mass.

The comparison of the distribution curves obtained (see Figure 2) revealed that considerable amounts (of more or less the same order of magnitude) of chloride were extracted. Chloride ions are known to react with the tricalcium aluminates present in cement to form Friedel's salt, $\mathrm{C}_{3} \mathrm{AH}_{10} \mathrm{CaCl}_{2}$ y $\mathrm{C}_{3} \mathrm{AH}_{32} \cdot 3 \mathrm{CaCl}_{2}$. These chlorides cannot be eliminated with ECE because they are unaffected by the electrical field generated. This, along with other factors, may explain why chloride extraction was under 100 per cent. Nonetheless, a decline in $\mathrm{pH}$ in the cementitious paste, induced by concrete carbonation, for instance, would invert chloride fixation and release the ions.

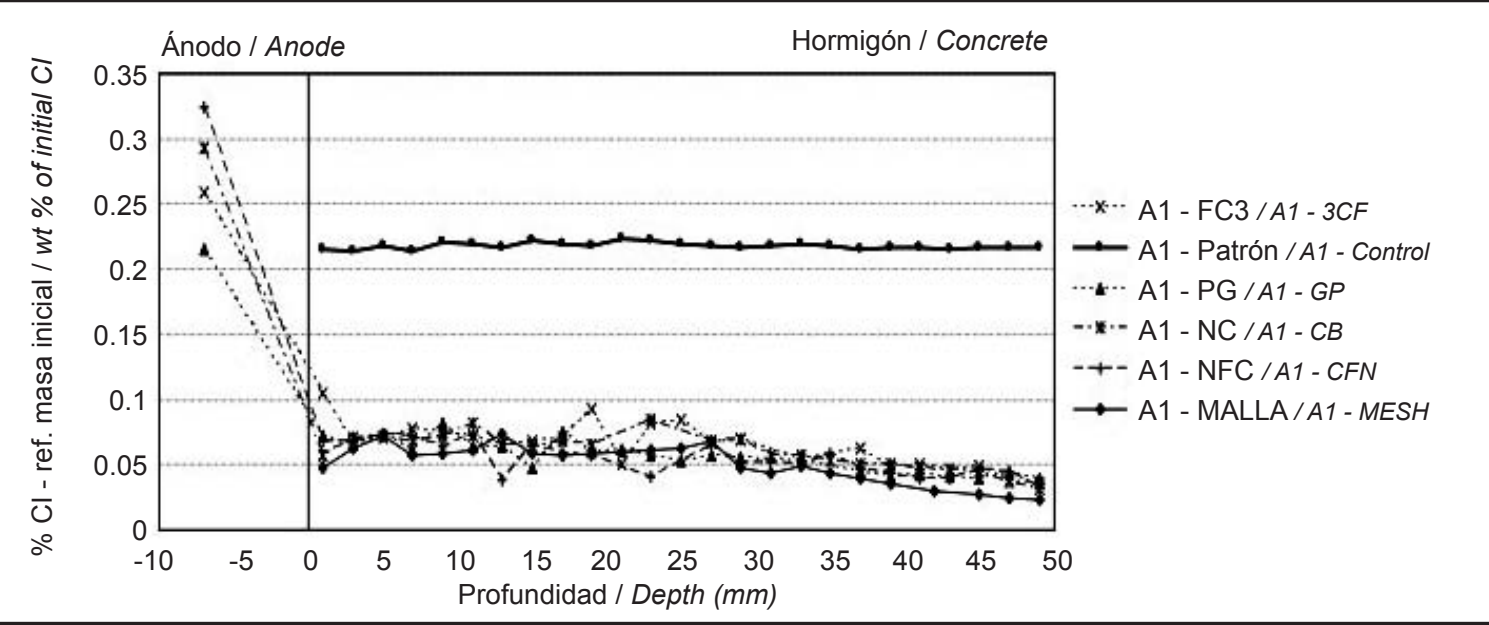

Figura 2. Contenido de cloruros antes y después de la aplicación de la EEC en bloques de hormigón contaminados $\operatorname{con} \mathrm{Cl}^{-}(0,22 \%$ respecto peso hormigón) utilizando ánodos con diferentes materiales carbonosos. Densidad de carga aplicada: $5 \times 10^{6} \mathrm{C} / \mathrm{m}^{2}$.

Figure 2. Chloride content before and after ECE in $\mathrm{Cl}^{-}$contaminated ( $0.22 \%$ of concrete mass) concrete blocks, found with anodes containing carbonaceous materials; charge density applied: $5 \times 10^{6} \mathrm{C} / \mathrm{m}^{2}$. 
Tabla 3 / Table 3

Datos experimentales de los ensayos desarrollados. Distribución del contenido del ión cloruro y eficiencias obtenidas en la aplicación de la técnica de EEC para la pasta de NFC comparativamente con los demás materiales carbonosos.

Conductive cement paste dosages / Test findings: comparison of chloride content distribution and ECE efficiency using CNF paste and other carbonaceous materials.

\begin{tabular}{|c|c|c|c|c|c|}
\hline $\begin{array}{c}\text { Material de sustitución/Adición / } \\
\text { Replacement/addition }\end{array}$ & $\begin{array}{c}\text { Hormigón / } \\
\text { Concrete (\%) }\end{array}$ & $\begin{array}{c}\text { Ánodo / } \\
\text { Anode (\%) }\end{array}$ & $\begin{array}{c}\text { Electrolito / } \\
\text { Electrolyte (\%) }\end{array}$ & $\begin{array}{c}\text { Balance / } \\
\text { Net(\%) }\end{array}$ & $\begin{array}{c}\text { Eficiencia / } \\
\text { Efficiency(\%) }\end{array}$ \\
\hline $\begin{array}{c}\text { Nanofibras de carbón (NFC) / } \\
\text { Carbon nanofibres (CNF) }\end{array}$ & 23.1 & 8.2 & 64.2 & 4.5 & 76.9 \\
\hline $\begin{array}{c}\text { Polvo de grafito (PG) / } \\
\text { Graphite powder (GP) }\end{array}$ & 23.8 & 6.6 & 54.4 & 15.3 & 76.2 \\
\hline $\begin{array}{c}\text { Fibra de carbón de 3 mm (FC3) / } \\
\text { 3-mm carbon fibre (3CF) }\end{array}$ & 27.6 & 8.5 & 38.0 & 25.9 & 72.4 \\
\hline $\begin{array}{c}\text { Negro de carbón (NC) / } \\
\text { Carbon black (CB) }\end{array}$ & 25.4 & 7.8 & 51.2 & 15.6 & 74.6 \\
\hline $\begin{array}{c}\text { Malla de Ti-RuO } / 2 \\
\text { Ti-RuO } \mathrm{O}_{2} \text { mesh }\end{array}$ & - & - & - & - & 72.6 \\
\hline
\end{tabular}

En la Figura 2 se puede observar, también, el perfil de cloruros obtenido para el caso de utilización de una malla de $\mathrm{Ti}^{-\mathrm{RuO}_{2}}$ como ánodo. Los resultados muestran que el nivel de extracción obtenido con este ánodo es muy similar a los anteriores, siendo en concreto la diferencia mostrada entre el ánodo con NFC y la malla de $\mathrm{Ti}^{-} \mathrm{RuO}_{2}$ menos del $1 \%$ de diferencia.

La Tabla 3 contiene los datos experimentales más relevantes de los ensayos desarrollados, junto con la distribución del contenido de ión cloruro, calculados por integración de los perfiles de cloruros y las eficiencias obtenidas en la aplicación de la EEC. Todos estos contenidos y eficiencias están expresados como porcentajes del contenido inicial de cloruros en el hormigón. El balance se calcula como la diferencia entre el contenido inicial total de cloruros en el hormigón y la suma de las cantidades presentes en cada fase (pasta de cemento conductora, electrolito y hormigón) tras la aplicación de la EEC. Dicha cantidad correspondería al ión cloruro eliminado en forma de gas cloro por reacción electroquímica sobre el ánodo. En términos generales cabe destacar el alto nivel de extracción de cloruros alcanzado con todas las pastas, siendo ligeramente superior el obtenido con las que contienen NFC. Por otra parte en la tabla se presentan los datos de porcentajes de cloruros retenidos en la pasta cementicia conductora. Esta retención de cloruros en el ánodo no es un dato positivo. Al finalizar la aplicación de la técnica, estos cloruros pueden reingresar en la capa de recubrimiento por redistribución de la concentración por difusión, especialmente si el hormigón es expuesto a un ambiente húmedo después de la $\operatorname{EEC}(25,26)$. Evitar esta redistribución es importante, puesto que puede reactivar el desarrollo de la corrosión de la armadura. Esto implica la conveniencia de eliminar la pasta cementicia conductora después de aplicar la EEC, y por lo tanto perder una de sus más interesantes características, la posibilidad del re-uso.
Figure 2 also shows the chloride profile obtained when $\mathrm{Ti}-\mathrm{RuO}_{2}$ mesh was used as the anode. According to these results, the extraction levels for this anode and the carbonaceous materials were similar, and the difference between the Ti-RuO 2 mesh and CNF was less than $1 \%$.

Table 3 lists the most prominent test findings, along with the distribution of chloride ion contents calculated by integrating the chloride curves and the ECE efficiency results. All these data are expressed as percentages of the initial chloride content in the concrete. The net sum was calculated as the difference between the total initial chloride content in the concrete and the sum of the amounts present in each phase (conductive cement paste, electrolyte and concrete) after applying ECE. That difference would be the amount of chloride ion eliminated as chlorine gas in the electrochemical reaction at the anode. A high level of chloride extraction was attained with all the pastes, although the values were slightly higher for the CNF materials. The table also gives the percentage of chlorides retained in the conductive cementitious paste. Retention of chlorides in the anode is not favourable, since postECE redistribution of the chloride concentration might induce ion diffusion back into the concrete cover, particularly in concrete exposed to moist environments $(25,26)$. Such redistribution must be avoided, for it may reactivate corrosion in the reinforcing steel. The inference is that the conductive cement paste should be removed after ECE, which would nullify one of its advantages: possible re-use. Research is presently underway on spraying conductive cement paste onto $\mathrm{Cl}^{-}$contaminated concrete. Given the thin layer (12-mm thick) of cement applied and its high porosity, 
Actualmente se está desarrollando una investigación en la aplicación, mediante proyección, de una fina capa de la pasta de cemento conductora. Dada las particulares características de esta capa proyectada: espesor de 1-2 mm y alto nivel de porosidad, el nivel de retención de cloruros es prácticamente nulo.

Por otra parte hay que considerar que si bien los materiales cementicios son dieléctricos, es decir, son malos conductores de la corriente eléctrica, la adición de materiales carbonosos conductores los transforman en materiales conductores. Estableciéndose así la posibilidad de realizar otras funciones distintas a la estructural, por ejemplo, como ánodo en la aplicación de la técnica de EEC. La pasta utilizada como ánodo es un material conductor, lo que garantiza que al conectarlo al polo positivo de la fuente de alimentación los iones cloruro, cargados negativamente, migren hacia él. Ahora bien hay que considerar si la homogeneidad del campo eléctrico es idéntica en todos los casos. Probablemente no. Si bien es cierto que con el porcentaje de adición conductora añadida en cada caso, se ha alcanzado el umbral de percolación, es decir, la cantidad mínima de adición conductora (NFC, FC3, PG o NC) necesaria para establecer un camino continuo de la corriente eléctrica, eso no significa haber conseguido en todos los casos la misma homogeneidad en la distribución del material carbonoso. Lo que explica las pequeñas diferencias obtenidas en los rendimientos. Fruto de la investigación desarrollada previamente se ha conseguido un alto nivel de homogenización en la distribución de las NFC, lo que explica su buen comportamiento, no solo en esta función de ánodo sino también en otras como la función de percepción de la deformación o la función de calefacción, objeto de sendas patentes $(27,28)$.

Finalmente hay que destacar, por otra parte, que la acumulación de cloruros que se produce en la pasta conductora no se da lógicamente cuando se utiliza un ánodo de malla de $\mathrm{Ti}-\mathrm{RuO}_{2}$, eliminándose los cloruros por electrolisis o permaneciendo en el electrolito. Sin embargo, este tipo de malla es menos flexible a la hora de aplicarlo a la superficie de una estructura de hormigón armado. La posibilidad de desarrollar una pasta cementicia conductora que pueda ser proyectada sobre una superficie de un elemento estructural (actualmente en fase de investigación), sea cual sea su geometría, plantea alcanzar un ánodo de más versátil aplicación que los ánodos tradicionales.

\section{CONCLUSIONES}

Los resultados de este trabajo muestran la viabilidad del uso de una pasta de cemento conductora mediante adición de nanofibras de carbón como ánodo en la aplicación de la técnica de extracción electroquímica de chloride retention would be practically nil in this gunned cement anode.

More generally, a number of considerations should be addressed with respect to the foregoing. The first is that while cement binders are dielectric, i.e., poor conductors of electricity, the inclusion of conductive carbonaceous materials makes them conductive and therefore apt for other than structural functions, such as anodes in ECE. The paste used here as an anode, for instance, was conductive and when connected to the positive pole on the power source attracted negatively charged chloride ions. A related issue is whether the electrical fields generated in the present study were equally uniform in all cases: in all likelihood, they were not. While the percentage of the conductive addition (CNF, 3CF, GP or CB) used in each case sufficed to attain the percolation threshold, i.e., the minimum needed to establish a continuous path for the electrical current that did not necessarily guarantee a consistently uniform distribution of the carbonaceous material. That effect would explain the minor differences observed in performance. The high level of uniformity attained in CNF distribution thanks to prior research would explain its good performance, not only as an anode but also when used for other purposes, such as detection of strain or for heating, both of which have been patented $(27,28)$.

Lastly, chlorides did not, logically, accumulate in the conductive paste when a $\mathrm{Ti}_{-} \mathrm{RuO} \mathrm{O}_{2}$ mesh was used, for they were either eliminated by electrolysis or retained in the electrolyte. Nonetheless, this type of mesh adapts less flexibly to the surfaces of reinforced concrete structures. The possibility of developing conductive cement paste that can be gunned onto the surface of any structural member regardless of its geometry is presently under study. From the standpoint of application, the resulting anode would be much more versatile than the traditional materials.

\section{CONCLUSION}

The results of this study reveal that a conductive cement paste containing carbon nanofibres can be used as an anode in electrochemical chloride extraction from concrete specimens. Its performance is comparable to 
cloruros a probetas de hormigón. La eficiencia obtenida es similar a la obtenida con otro ánodo tradicional como es la malla de $\mathrm{Ti}-\mathrm{RuO}_{2}$.

\section{AGRADECIMIENTOS}

Los autores agradecen la financiación concedida a través de los siguientes proyectos para la realización de este trabajo: Ministerio de Ciencia e Innovación y FEDER (Ref: Mat2009-10866 y BIA2010-20548). the efficiency obtained with traditional $\mathrm{Ti}-\mathrm{RuO}_{2}$ mesh anodes.

\section{ACKNOWLEDGEMENTS}

This research was funded by the Spanish Ministry of Science and Innovation and ERDF, under projects Mat2009-10866 and BIA2010-20548.

\section{BIBLIOGRAFÍA / BIBLIOGRAPHY}

(1) Slater, J. E.; Lankard, D. R.; Moreland, P. J.: "Electrochemical removal of chlorides from concrete bridge decks". Mater. Perform., 15 (1976), pp. 21-26. ISSN: 03611981.

(2) Vennesland, O.; Opsahl, O. A.; Russell-Rayner, A. P.: Removal of chlorides from concrete, European Patent Application number 86302888.2, Publication number 0200428 (1986).

(3) Roper, H.: Method for inhibiting concrete cancer, World Intellectual Property Organization, International Patent Publication number WO 93/21130 (1993).

(4) Bennett, J. E.; Blasius, J. R.; Mitchell, T. A.; Turk, T. R.; Schue, T. J.: Apparatus for the removal of chloride from reinforced concrete structures. U.S. Patent number 5296120 (1994).

(5) Elsener, B.; Böhni, H.: "Electrochemical chloride removal field test", en R.N. Swamy (ed.), Corrosion and Corrosion Protection of Steel in Concrete, vol. 2, Sheffield Academic Press, Sheffield, U.K. (1994), pp. 1451-1462.

(6) Hope, B. B.; Ihekwaba, N. M.; Hansson, C. M.: "Influence of multiple rebar mats on electrochemical removal of chloride ions from concrete", Materials Science Forum, vols. 192-194 (1995), pp. 883-890. ISSN: 02555476.

(7) Andrade, C.; Castellote, M.; Alonso, C.: "An overview of electrochemical realkalisation and chloride extraction", en Ho, D.W.S., Godson, I. and Collins, F.(eds.), Proceedings of 2nd Int. RILEM/CSIRO/ACRA Conference on Rehabilitation of Structures, Melbourne, Australia (1998), pp. 1-12.

(8) Tritthart, J.: Electrochemical chloride removal: an overview and scientific aspects, en Skalny, J. y Mindess, S. (eds.), Materials Science of Concrete V, published by the American Ceramic Society, Westerville, Ohio, USA (1998), pp. 401-441.

(9) Electrochemical Rehabilitation Methods for Reinforced Concrete Structures. A State of the Art Report, J. Mietz, ed., Publication number 24 of the European Federation of Corrosion, IOM Communications Ltd., London (1998), p. 57.

(10) Orellan, J. C.; Escadeillas, G.; Arliguie, G.: "Electrochemical chloride extraction: efficiency and side effects", Cem. Concr. Res., 34 (2004), pp. 227-234. DOI: 10.1016/j.cemconres.2003.07.001.

(11) Polder, R. B.: "Electrochemical techniques for corrosion protection and maintenance", en Böhni, H. (ed.), Corrosion in Reinforced Concrete Structures, Woodhead Publishing, Cambridge, UK (2005), pp. 215-241.

(12) Climent, M. A.; Sánchez de Rojas, M. I.; de Vera, G.; Garcés, P.: "Effect of type of anodic arrangements on the efficiency of electrochemical chloride removal from concrete", ACI Mat. J., 103 (4) (2006), pp. 243-250. ISSN: 0889325X.

(13) Yeih, W.; Chang, J. J.; Hung, C. C.: "Selecting an adequate procedure for the electrochemical chloride removal", Cem. Concr. Res., 36 (2006), pp. 562-570. DOI: 10.1016/j.cemconres.2005.12.008.

(14) Garcés, P.; Sánchez de Rojas, M. I.; Climent, M. A.: "Effect of the reinforcement bar arrangement on the efficency of electrochemical chloride removal technique applied to reinforced concrete structures", Corros. SCi., 48 (3) (2006), pp. 531-545. DOI: 10.1016/j.corsci.2005.02.010.

(15) Miranda, J. M.; González, J. A.; Cobo, A.; Otero, E.: "Several questions about electrochemical rehabilitation methods for reinforced concrete structures", Corros. Sci, 48 (2006), pp. 2172-2188. DOI: 10.1016/j.corsci.2005.08.014.

(16) Sánchez de Rojas, M. J.; Garcés, P.; Climent, M. A.: "Extracción electroquímica de cloruros del hormigón armado: estudio de diferentes variables que influyen en la eficacia del tratamiento", Mater. Construcc., 56 (284) (2006), pp. 7-26. ISSN: 04652746.

(17) Toumi, A.; François, R.; Alvarado, O.: "Experimental and numerical study of electrochemical chloride removal from brick and concrete specimens", Cem. Concr. Res., 37 (2007), pp. 54-62. DOI: 10.1016/j.cemconres.2006.09.012.

(18) Miranda, J. M.; Cobo, A.; Otero, E.; González, J. A.: "Limitations and advantages of electrochemical chloride removal in corroded reinforced concrete structures", Cem. Concr. Res., 37 (2007), pp. 596-603. DOI: 10.1016/j.cemconres.2007.01.005.

(19) Abdelaziz, G. E.; Abdelalim, A. M. K.; Fawzy, Y. A.: "Evaluation of the short and long-term efficiencies of electro-chemical chloride extraction", Cem. Concr. Res., 39 (2009) pp. 727-732. DOI: 10.1016/j.cemconres.2009.05.015.

(20) Pérez, A.; Climent, M. A.; Garcés, P.: "Electrochemical extraction of chlorides from reinforced concrete using a conductive cement paste as an anode", Corros. Sci., 52 (2010) pp. 1576-1581. DOI: 10.1016/j.corsci.2010.01.016. 
(21) Bertolini, L.; Bolzoni, F.; Pastore, T.; Pedeferri, P.: "Effectiveness of a conductive cementitious mortar anode for cathodic protection of steel in concrete", Cem. Concr. Res., 34 (4) (2004), pp. 681-694. DOI: 10.1016/j.cemconres.2003.10.018.

(22) Xu, J.; Yao, W.: "Current distribution in reinforced concrete cathodic protection system with conductive mortar overlay anode", Const. Build. Mat., 23 (6) (2009), pp. 2220-2226. DOI: 10.1016/j.conbuildmat.2008.12.002.

(23) Profile Grinder (PF-1100), Germann Instruments A/S, Copenhagen, Denmark (1996).

(24) Climent, M. A.; de Vera, G.; Viqueira, E.; López, M. M.: "Generalization of the possibility of eliminating the filtration step in the determination of acid-soluble chloride content in cement and concrete by potentiometric titration", Cem. Concr. Res., 34 (12) (2004), pp. 2291-2295. DOI: 10.1016/j.cemconres.2004.04.012.

(25) Climent, M. A.; Viqueira, E.; de Vera G.; López M. M.: "Chloride contamination of concrete by interaction with PVC combustion gases", Cem. Concr. Res., 28 (2) (1998), pp. 209-219.

(26) De Vera, G.; Climent, M. A.; Viqueira, E.; Antón, C.: Andrade, C.: "A test method for measuring chloride diffusion coefficients through partially saturated concrete. Part II: The instantaneous plane source diffusion case with chloride binding consideration", Cem. Concr. Res., 37 (5) (2007), pp. 714-724. DOI: 10.1016/J.cemconres.2007.01.008

(27) Garcés P.; Galao O.; Zornoza, E.; Baeza J. (Investigador responsable): Composite cementicio con nanofibras de carbono para monitorización de deformaciones, Solicitud de Patente: P200901735.

(28) Garcés P.; Galao O.; Zornoza, E.; Baeza J. (Investigador responsable): Composite cementicio con nanofibras de carbono para calefacción, Solicitud de Patente: P200901735. 